\title{
Oral health care of hospitalized elderly in a Southern Brazilian public hospital
}

\author{
Atenção à saúde bucal para idosos hospitalizados em um hospital público do sul do Brasil \\ Atención a la salud bucal de ancianos hospitalizados en un hospital público del Sur de Brasil
}

Received: 02/04/2022 | Reviewed: 02/15/2022 | Accept: 02/19/2022 | Published: 02/28/2022

\author{
Cristiano Regis Alba \\ ORCID: https://orcid.org/0000-0002-4721-5856 \\ Health Secretary of the State of Santa Catarina, Brazil \\ E-mail: cristianoalba@unochapeco.edu.br \\ Chris Netto de Brum \\ ORCID: https://orcid.org/0000-0002-2970-1906 \\ Universidade Federal da Fronteira Sul, Brazil \\ E-mail: crhis.brum@uffs.edu.br \\ Rafaela Lasta \\ ORCID: https://orcid.org/0000-0001-9168-1339 \\ Private dental office, Brazil \\ E-mail: rafaela.lasta@unochapeco.edu.br \\ Michele Gassen Kellermann \\ ORCID: https://orcid.org/0000-0003-3478-4977 \\ Universidade Comunitária da Região de Chapecó, Brazil \\ E-mail: mkellermann@unochapeco.edu.br \\ Vanessa da Silva Corralo \\ ORCID: https://orcid.org/0000-0003-4234-4875 \\ Universidade Comunitária da Região de Chapecó, Brazil \\ E-mail: vcorralo@unochapeco.edu.br \\ Otávio Pereira D'Ávila \\ ORCID: https://orcid.org/0000-0003-1852-7858 \\ Universidade Federal de Pelotas, Brazil \\ E-mail: otaviopereiradavila@gmail.com \\ Clodoaldo Antônio de Sá \\ ORCID: https://orcid.org/0000-0001-7409-8870 \\ Universidade Comunitária da Região de Chapecó, Brazil \\ E-mail: clodoaldo@unochapeco.edu.br \\ Sinval Adalberto Rodrigues-Junior \\ ORCID: https://orcid.org/0000-0002-4475-1725 \\ Universidade Comunitária da Região de Chapecó, Brazil \\ E-mail: rodriguesjunior.sa@unochapeco.edu.br
}

\begin{abstract}
Oral health care plays a part in the integral recovery of hospitalized older people. Based on that, this study characterized the oral health care of hospitalized older people in a Brazilian public hospital. Through application of questionnaires, this cross-sectional study assessed oral health care practice by hospital nursing staff $(n=31)$, companions $(n=134)$ and hospitalized older people $(n=200)$ of a public hospital in Southern Brazil. Clinical examination was conducted by two previously calibrated examiners to screen the oral health condition of the patients, considering the presence of cavitated lesions, residual roots, visible biofilm, calculus, gum inflammation and bleeding. Data were analysed descriptively. Nursing staff limits oral health assessment to surgical procedures; 55\% of nurses and $58 \%$ of companions do not supervise the oral hygiene, but $81 \%$ and $96 \%$, respectively, claim to perform oral hygiene of elderly with difficulties to do so. The elderly (51\%) claimed to brush their teeth $3 \mathrm{x} /$ day or more; yet, their oral health was characterized by the presence of visible biofilm, calculus, gingival inflammation and bleeding and decayed teeth. Oral health advisory or assessment is not part of the hospital routine. Companions and hospital nursing staff are willing to receive oral health care information. Poor oral health was observed in hospitalized older people, which would probably be enhanced by an interdisciplinary educational approach towards oral health care to older patients.
\end{abstract}

Keywords: Oral health care; Elderly; Caregiver; Oral health; Nursing staff.

\section{Resumo}

A atenção à saúde bucal faz parte da recuperação integral do idoso hospitalizado. Com base nisso, este estudo caracterizou a atenção à saúde bucal de idosos internados em um hospital público brasileiro. Por meio da aplicação de questionários, este estudo transversal avaliou a prática assistencial em saúde bucal da equipe de enfermagem hospitalar $(n=31)$, acompanhantes $(n=134)$ e idosos hospitalizados $(n=200)$ de um hospital público do Sul do Brasil. O 
exame clínico foi realizado por dois examinadores previamente calibrados para triagem do estado de saúde bucal dos pacientes, considerando a presença de lesões cavitadas, raízes residuais, biofilme visível, cálculo, inflamação gengival e sangramento. Os dados foram analisados descritivamente. A equipe de enfermagem limita a avaliação da saúde bucal aos procedimentos cirúrgicos; $55 \%$ dos enfermeiros e 58\% dos acompanhantes não supervisionam a higiene bucal, mas $81 \%$ e $96 \%$, respectivamente, afirmam realizar a higiene bucal de idosos com dificuldades. Os idosos $(51 \%)$ relataram escovar os dentes 3 vezes ao dia ou mais; no entanto, sua saúde bucal foi caracterizada pela presença de biofilme visível, cálculo, inflamação e sangramento gengival e dentes cariados. A avaliação da saúde bucal não faz parte da rotina hospitalar. Acompanhantes e equipe de enfermagem do hospital estão dispostos a receber informações sobre cuidados com a saúde bucal. Uma saúde bucal precária foi observada nos idosos hospitalizados, o que provavelmente melhoraria com uma abordagem educacional interdisciplinar para os cuidados com a saúde bucal dos pacientes idosos.

Palavras-chave: Atenção à saúde bucal; Idosos; Cuidador; Saúde bucal; Equipe de enfermagem.

\section{Resumen}

El cuidado de la salud bucal forma parte de la recuperación integral de las personas mayores hospitalizadas. Con base en eso, este estudio caracterizó la atención a la salud bucal de ancianos hospitalizados en un hospital público brasileño. A través de la aplicación de cuestionarios, este estudio transversal evaluó la práctica del cuidado de la salud bucal del personal de enfermería hospitalario ( $n=31)$, acompañantes $(n=134)$ y ancianos hospitalizados $(n=200)$ de un hospital público en el Sur de Brasil. El examen clínico fue realizado por dos examinadores previamente calibrados para tamizar el estado de salud bucal de los pacientes, considerando la presencia de lesiones cavitadas, raíces residuales, biopelícula visible, cálculo, inflamación de las encías y sangrado. Los datos se analizaron descriptivamente. El personal de enfermería limita la evaluación de la salud bucal a los procedimientos quirúrgicos; el $55 \%$ de las enfermeras y el 58\% de los acompañantes no supervisan la higiene bucal, pero el $81 \%$ y el $96 \%$, respectivamente, afirman realizar la higiene bucal de los ancianos con dificultades para hacerlo. Los ancianos (51\%) afirmaron cepillarse los dientes 3 veces al día o más; sin embargo, su salud oral se caracterizó por la presencia de biopelícula visible, cálculo, inflamación gingival y dientes cariados y sangrantes. El asesoramiento o la evaluación de la salud bucal no forma parte de la rutina del hospital. Los acompañantes y el personal de enfermería del hospital están dispuestos a recibir información sobre el cuidado de la salud bucal. Se observó una mala salud bucal en los ancianos hospitalizados, lo que probablemente mejoraría con un enfoque educativo interdisciplinario hacia el cuidado de la salud bucal de los pacientes mayores.

Palabras clave: Cuidado de la salud bucal; Ancianos; Cuidador; Salud bucal; Personal de enfermería.

\section{Introduction}

Populational ageing is a recognizable phenomenon that has involved both, developed and developing countries (Khan, 2018). Estimations are that the proportion of elderly people will increase from 2010 to 2050 in rates varying from 8.2 to $37.8 \%$, depending on the country (Ezehv et al., 2012), and this may have a significant effect on economics and health care (Khan, 2018).

Characteristically, ageing increases the risk of chronic-degenerative diseases, resulting in frailty. Frail elders are prone to decline of physical status and activities and increased vulnerability to adverse health events (Tanaka et al., 2018). Consequently, hospitalization increases dramatically with age due to chronic diseases, such as cardiovascular diseases, cancer, pulmonary disease, diabetes, rheumatoid arthritis among others (Carrilho Neto et al., 2011a; Hajat \& Stein, 2018; H. Wang et al., 2016).

During the hospitalization period oral health problems may aggravate the systemic condition of the hospitalized elder, regardless of the disease that led to hospitalization (Gil-Montoya et al., 2015). High prevalence of caries, periodontal disease, edentulism, xerostomia and oral cancer has been identified associated to elderly people (Gil-Montoya et al., 2015; Murray Thomson, 2014). Poor oral health leads to malnutrition (Kamdem et al., 2017), physical frailty (Tanaka et al., 2018) and respiratory infections that ultimately may cause death (Awano et al., 2008; Hua et al., 2016; Van Der Maarel-Wierink et al., .

Considering the impact oral health has on the recovery capability of a hospitalized elder, some prevention strategies have been suggested. Regular oral health assessment, implementation of daily oral health hygiene measures, permanent education of care givers and hospital nursing staff may help preventing further harm caused by a poor oral health condition in hospitalized elderly, such as respiratory diseases (Coker et al., 2017a; Rantzow et al., 2018). Oral health maintenance, in this 
context, would be performed by hospital nursing staff and caregivers (Razak et al., 2014). In fact, oral health of hospitalized elderly has been shown to benefit from training on oral health care routines offered to hospital nurses (Gibney et al., 2019). On the other hand, attention to oral care measures in hospitals are still scarce, as well as the presence of a dentist amongst the staff.

Taking into consideration the possibility that oral health care training in hospital environment still is mostly the exception than the rule, this study aimed to characterize knowledge and practices on oral health by hospital nursing staff, hospitalized elderly and their companions. Also, it verified the oral health condition of hospitalized elderly.

\section{Methodology}

\subsection{Design and setting}

This study was conceived as a cross-sectional study, descriptive study of quantitative nature (Medronho et al., 2009) and was held in the Regional Hospital Terezinha Gaio Basso of São Miguel do Oeste, Southern Brazil. The hospital is public, attending by the Brazilian Unified Health System (SUS) demands of medium complexity and is maintained by the government of the State of Santa Catarina since 2011. The hospital covers the population of 30 municipalities in the extreme west of the State of Santa Catarina, estimated in 230.000 people. Data were collected from February 2019 to June 2019, after approval of the study proposal by the Research Ethics Committee of the local community university, under protocol no. 2.959.861.

\subsection{Participants}

Participants of the study involved the hospital nursing staff (nurses and nursing technicians) working in the medical and surgical clinics. Staff members who were on vacation or health licence during the study were excluded. Hospitalized people over 60 years in the medical and surgical clinics, considered older people in developing countries by the World Health Organization (WHO) and their companions were also included. Companions were considered those accompanying the hospitalized elderly and were all invited to take part of the study. Inclusion of the participants took into consideration those who were hospitalized when examiners went to the hospital, based on the hospital records. The chief nurse screened them for inclusion before clinical examination. Patients isolated by the Hospital Infection Control Commission, patients in palliative care and patients with cognitive impairment or incapable of answering the questionnaire were excluded. Cognitive impairment was screened by the main author (CRA) using the Minimental test, with a varying score of 0 to 30 points. The following cut off points were adopted to exclude a participant: below 13 points for non-literate, below 18 points for those with 1-11 years of schooling and below 26 points for those with more than 11 years of schooling (Crum et al., 1993).

All available and eligible members of the hospital nursing staff participated of the study $(n=31)$. A numerically precise sample size for hospitalized elders was calculated based on the number of hospitalizations and proportion of companions along three months of 2018 (May, June and July). A sample size of 111 hospitalized elders and 105 companions were calculated using a finite population proportion sample size (https://select-statistics.co.uk/calculators/sample-sizecalculator-population-proportion/), based on a sampling error $(\alpha)$ of $5 \%$ and a confidence level of $95 \%$. Still, considering the perspective of further inferential analysis, the sample size was extended to 200 hospitalized elders and their 134 companions. All participants agreed to take part of the study by signing a two-way consent term after being clarified about the possibility of dropping out of the study at any moment, with no harm of any nature.

\subsection{Instruments}

Self-applicable questionnaires were built involving sociodemographic variables and questions relative to oral hygiene knowledge and practices by hospital nursing staff, companions and hospitalized elderly. These instruments were based on previous studies (Fernandes et al., 2016; Kahn et al., 2008; Oliveira et al., 2015; Vieira et al., 2011). 
A clinical data collection form was also built based on previous oral health surveys (Brasil, 2011; Wang et al., 2015; WHO, 2013), and considered the following clinical variables: presence/absence of cavitated carious lesions, presence/absence of residual roots, presence/absence of visible biofilm, presence/absence of calculus, presence/absence of gum inflammation, gum bleeding at probing.

\subsection{Training and calibration of clinical examiners}

Aiding at collecting the clinical oral health status of the hospitalized elders, two dentists were previously trained and went through a calibration process. Training involved discussion meetings at two moments with slide projections of the clinical variables and criteria were set for clinical examination by consensus. Following, hospital patients with similar characteristics of our target sample were examined for calibration purposes. These patients were sequentially invited amongst those hospitalized and agreed to be orally examined. A minimum Cohen's Kappa coefficient of 0.6 was set for inter-examiner agreement.

\subsection{Procedure}

All participants were informed about the study purposes and signed an informed consent form. They also were clarified that they were free to leave the study at any moment. Patients were sequentially screened twice a week, and those who agreed to participate answered the questionnaires. Those who could not answer it due to illiteracy were interviewed by a researcher. When companions were present and agreed to participate, they were also enrolled in the study. Clinical examination was held at room light, with sterile gauze, clinical mirror, wooden spatula and CPI periodontal probe. Calculus was considered present when identified in the surface of the tooth, dental implant or denture. Bleeding by probing was checked by gentle probing of the gingival sulcus with the CPI probe. The other items were assessed visually. The nursing staff had their data collected later by self-applied questionnaires, so a shift in their behaviour towards oral health of their patients by awareness of the study taking place was unlikely to occur.

\subsection{Data analysis}

Data were analysed by descriptive statistics (mean, standard deviation (SD), minimum and maximum for numerical variables and absolute and relative frequencies along with the $95 \%$ confidence interval (95\% CI) for categorical variables).

\section{Results}

In total, 21 patients other than those included in the study were clinically examined for calibration purposes, in two moments. After the first 12 examinations, data were analysed using Cohen's Kappa. Following, concepts and criteria were revised, and the rest of the patients were then examined. Kappa for the presence of cavitated lesions, residual roots, visible biofilm, calculus, gingival inflammation and bleeding were $0.877,1.000,0.618,0.323,1.000$ and 0.710 , respectively. The Kappa value related to the presence of calculus was low due to inconsistencies related to the first set of examinations. After revision, the consistency of the second set of examinations reached 1.000. Therefore, regardless of the low Kappa value for this variable, both examiners were maintained.

Amongst the hospital nursing staff $(n=31), 84 \%$ were female. The mean age was $35,3 \pm 9,3$, with a minimum of 20 and a maximum of 54 years. Nurses accounted for $29 \%$ and nursing technicians for $71 \%$; $38.7 \%$ worked in the field from 1 to 5 years and $45.2 \%$ from 6 to 10 years. Graduated only nurses accounted for $25.8 \%$, while specialists corresponded to $51.6 \%$ and those with professional improvement courses corresponded to $22.6 \%$. 
The total of 134 companions were included in the study. Female companions accounted for 65\%. The mean age was of $49.6 \pm 13.4$ years, with a minimum of 19 and a maximum of 80 years. Forty-nine per cent studied from 4 to 7 years and $40 \%$ for 11 years or more. Only two companions (1.5\%) were formal caregivers, meaning that they were hired to take care of the patient; $52 \%$ of the informal companions were categorized as daughter/son or partner (25\%). Ninety per cent claim having been trained to work with older people.

Two hundred hospitalized elderly were included in the study, with $69.5 \%$ being male. The mean age was $72.4 \pm 7.7$, with a minimum of 60 and a maximum of 90 years. Almost $80 \%$ did not complete elementary schooling. The mean hospitalization time was $90.4 \pm 75.8$ hours, with a minimum of 26 and a maximum of 552 hours; $55 \%$ were located at the medical clinics and $45 \%$ in the surgical clinics. Twenty-seven per cent of the hospitalized patients had registration of aspiration pneumonia.

Table 1 presents the practice and knowledge of oral health care by hospital nursing staff. When it comes to mechanical ventilation, $93.5 \%$ believes that patients undergoing mechanical ventilation need oral hygiene measures; $93.5 \%$ believes that ventilation-associated pneumonia is related to oral hygiene of the patient, and $100 \%$ believes that patients undergoing nasogastric, nasoenteral tube, jejunum or gastrostomy require oral hygiene measures; 52\% believes that dentures should be removed at night time and $100 \%$ believes oral hygiene should be provided to those with no teeth or denture.

Table 1. Practices and knowledge of oral health care of hospitalized elderly by hospital nursing staff $(n=31)$.

\begin{tabular}{|c|c|c|}
\hline Practice & n $(\%)$ & $95 \% \mathrm{CI}$ \\
\hline \multicolumn{3}{|c|}{ Do you assess the oral health of an older person at hospitalization? } \\
\hline Yes & $14(45)$ & $27.5-62.5$ \\
\hline No & $17(55)$ & $37.5-72.5$ \\
\hline \multicolumn{3}{|c|}{$\begin{array}{l}\text { A patient hospitalized for a surgical procedure should have the oral } \\
\text { health assessed? }\end{array}$} \\
\hline Yes & $24(77)$ & $62.2-91.8$ \\
\hline No & $7(23)$ & $8.2-37.8$ \\
\hline \multicolumn{3}{|c|}{ Do you supervise the hospitalized elderly during oral hygiene? } \\
\hline Yes & $14(45)$ & $27.5-62.5$ \\
\hline No & $17(55)$ & $37.5-72.5$ \\
\hline \multicolumn{3}{|c|}{ Do you perform the oral hygiene for a patient with limitations do to so? } \\
\hline Yes & $25(81)$ & $67.2-94.8$ \\
\hline No & $6(19)$ & $5.2-32.8$ \\
\hline \multicolumn{3}{|c|}{$\begin{array}{l}\text { When an older patient has physical or mental limitations to perform oral } \\
\text { hygiene, you }\end{array}$} \\
\hline Ask the companion/caregiver to do it & $20(65)$ & $48.2-81.8$ \\
\hline Do it once a day & $3(9.5)$ & $-0.8-19.8$ \\
\hline Do it twice a day & $2(6.5)$ & $-2.2-15.2$ \\
\hline Do it three times or more & $6(19)$ & $5.2-32.8$ \\
\hline \multicolumn{3}{|c|}{ Do you have any difficulty to perform oral hygiene in your patients } \\
\hline Yes & $6(19)$ & $5.2-32.8$ \\
\hline No & $25(81)$ & $67.2-94.8$ \\
\hline \multicolumn{3}{|l|}{ Dificulties declared $(n=6)$} \\
\hline Lack of acceptance by the patient & $1(17)$ & $3.8-30.2$ \\
\hline Lack of time & $3(50)$ & $32.4-67.6$ \\
\hline Others & $2(33)$ & $16.4-49.6$ \\
\hline \multicolumn{3}{|l|}{ Knowledge } \\
\hline \multicolumn{3}{|c|}{ Have you received information about oral health? } \\
\hline Yes & $25(81)$ & $67.2-94.8$ \\
\hline No & $6(19)$ & $5.2-32.8$ \\
\hline \multicolumn{3}{|c|}{ Are you interested in receiving information about oral health? } \\
\hline Yes & $30(97)$ & $91.0-103.0$ \\
\hline No & $1(3)$ & $-3.0-9.0$ \\
\hline \multicolumn{3}{|c|}{$\begin{array}{l}\text { Do you believe oral health can influence the treatment of an older } \\
\text { patient? }\end{array}$} \\
\hline Yes & $30(97)$ & $91.0-103.0$ \\
\hline No & $1(3)$ & $-3.0-9.0$ \\
\hline
\end{tabular}


Research, Society and Development, v. 11, n. 3, e38711326565, 2022

(CC BY 4.0) | ISSN 2525-3409 | DOI: http://dx.doi.org/10.33448/rsd-v11i3.26565

What you should do if, during brushing, the gums start bleeding?

Should stop brushing

$4(13)$

$21(67.5)$

Brushing more frequently

Do you know what periodontal disease is?

Yes

No

In your opinion, does any of the systemic conditions relate to periodontal

disease?

Respiratory diseases

Cardiovascular diseases

Diabetes Mellitus (DM)

Respiratory and cardiovascular diseases

Cardiovascular diseases and DM

None of the above

Is there any oral hygiene protocol in your hospital?

Yes

No
$6(19.5)$

$24(77.5)$

$7(22.5)$

$6(19)$

$9(29)$

$1(3)$

$4(13)$

$1(3)$

$10(33)$

$9(29)$

$22(71)$
$1.2-24.8$

$51.0-84.0$

5.6-33.4

$62.8-92.2$

7.8-3.2

7.8-37.2

$13.0-45.0$

$-3.0-9.0$

$1.2-24.8$

$-3.0-9.0$

$16.4-49.6$

$13.0-45.0$

$55.0-87.0$

Source: Authors (2022).

Table 2 presents the practice and knowledge of oral health care by companions. All companions believe that dentures should be cleaned every time they are removed. Yet, $50 \%$ believes that dentures should be worn during night and day, while $19.4 \%$ believe they should be removed at night-time; $18.6 \%$ does not know how to proceed. Most companions (98.5\%) believe oral hygiene should be provided to those with no teeth or denture. 
Table 2. Practices and knowledge of oral health care of hospitalized elderly by companions/caregivers $(n=134)$.

\begin{tabular}{|c|c|c|}
\hline Practice & n $(\%)$ & $95 \% \mathrm{CI}$ \\
\hline \multicolumn{3}{|c|}{ Do you supervise the hospitalized elderly during oral hygiene? } \\
\hline Yes & $57(42.5)$ & $34.1-50.9$ \\
\hline No & $77(57.5)$ & $49.1-65.9$ \\
\hline \multicolumn{3}{|c|}{ Do you perform the oral hygiene for a patient with limitations do to so? } \\
\hline Yes & $129(96)$ & $92.7-99.3$ \\
\hline No & $5(4)$ & $0.7-7.3$ \\
\hline \multicolumn{3}{|c|}{$\begin{array}{l}\text { When an older patient has physical or mental limitations to perform oral } \\
\text { hygiene, you }\end{array}$} \\
\hline Do not do it & $4(3)$ & $0.1-5.9$ \\
\hline Do it once a day & $4(3)$ & $0.1-5.9$ \\
\hline Do it twice a day & $24(18)$ & $11.5-24.5$ \\
\hline Do it three times or more & $102(76)$ & $68.8-83.2$ \\
\hline \multicolumn{3}{|l|}{ Knowledge } \\
\hline \multicolumn{3}{|c|}{ Have you received information about oral health? } \\
\hline Yes & $83(62)$ & $52.0-65.8$ \\
\hline No & $51(38)$ & $34.2-47.8$ \\
\hline \multicolumn{3}{|c|}{ Are you interested in receiving information about oral health? } \\
\hline Yes & $134(100)$ & $100.0-100.0$ \\
\hline No & $0(0)$ & $0.0-0.0$ \\
\hline \multicolumn{3}{|c|}{$\begin{array}{l}\text { Do you believe oral health can influence the treatment of an older } \\
\text { patient? }\end{array}$} \\
\hline Yes & $134(100)$ & $100.0-100.0$ \\
\hline No & $0(0)$ & $0.0-0.0$ \\
\hline \multicolumn{3}{|c|}{ Have you been advised on oral health care by a dentist? } \\
\hline Yes & $92(68.7)$ & $60.8-76.6$ \\
\hline No & $42(31.3)$ & 23.4-39.2 \\
\hline \multicolumn{3}{|c|}{ Do you believe that brushing the teeth is important? } \\
\hline Yes & $133(99.3)$ & $97.9-100.7$ \\
\hline No & $1(0.7)$ & $-0.7-2.1$ \\
\hline \multicolumn{3}{|c|}{ What you should do if, during brushing, the gums start bleeding? } \\
\hline Do not know what to do & $6(4.5)$ & $1.0-8.0$ \\
\hline Should stop brushing & $6(4.5)$ & $1.0-8.0$ \\
\hline Be more carefull at brushing & $48(35.8)$ & $27.7-43.9$ \\
\hline Brushing more frequently & $13(9.7)$ & $2.2-17.2$ \\
\hline Inform the nursing staff & $61(45.5)$ & $37.1-53.9$ \\
\hline
\end{tabular}

Source: Authors (2022).

Table 3 presents the oral health practices of the hospitalized elderly, while Figure 1 presents features of their oral health condition.

Table 3. Practices and knowledge of oral health care by hospitalized elderly $(n=200)$.

\begin{tabular}{lcc}
\hline Practice & $\mathbf{n}(\%)$ & $\mathbf{9 5 \%} \mathbf{C I}$ \\
\hline Did you brush your teeth in the day you participated of the study? & & \\
$\quad$ Yes & $118(59)$ & $52.2-65.8$ \\
$\quad$ No & $82(41)$ & $34.2-47.8$ \\
Daily toothbrushing frequency & $7(3.5)$ & $1.0-6.0$ \\
$\quad$ None & $19(9.5)$ & $5.4-13.6$ \\
$\quad$ Once & $72(36)$ & $29.3-42.7$ \\
$\quad$ Twice & $102(51)$ & $44.0-57.9$ \\
$\quad$ Three times or more & $190(95)$ & $92.0-98.0$ \\
Do you use fluoridated toothpaste? & $9(4.5)$ & $1.6-7.4$ \\
$\quad$ Yes & $1(0.5)$ & $0.5-1.5$ \\
$\quad$ No & $12(6)$ & $2.7-9.3$ \\
$\quad$ Not applicable & $188(94)$ & $90.7-97.3$ \\
Do you floss? & & \\
$\quad$ Yes & $20(10)$ & $5.8-14.2$ \\
$\quad$ No & \\
Do you use mouthrinse? & \\
$\quad$ Yes &
\end{tabular}




\begin{tabular}{|c|c|c|}
\hline No & $180(90)$ & $85.8-94.2$ \\
\hline \multicolumn{3}{|c|}{ Do you believe that brushing your teeth is important? } \\
\hline Yes & $195(97.5)$ & 95.3-99.7 \\
\hline No & $5(2.5)$ & $0.3-4.7$ \\
\hline \multicolumn{3}{|l|}{ Do you wear denture? } \\
\hline Yes & $167(83.5)$ & 78.4-88.6 \\
\hline No & $33(16.5)$ & $11.4-21.6$ \\
\hline \multicolumn{3}{|c|}{ Do you remove your denture during sleep? } \\
\hline Yes & $38(19)$ & $13.6-24.4$ \\
\hline No & $129(64.5)$ & $57.9-71.1$ \\
\hline Not applicable & $33(16.5)$ & $11.4-21.6$ \\
\hline \multicolumn{3}{|c|}{ When was your last visit to the dentist? } \\
\hline Never consulted a dentist & $3(1.5)$ & $-0.2-3.2$ \\
\hline Less than six months & $29(14.5)$ & $9.6-19.4$ \\
\hline Less than one year & $19(9.5)$ & $5.4-13.6$ \\
\hline Between 1 and 3 years & $56(28)$ & $21.8-34.2$ \\
\hline Between 3 and 5 years & $31(15.5)$ & $10.5-20.5$ \\
\hline More than 5 years & $62(31)$ & $24.6-37.4$ \\
\hline \multicolumn{3}{|c|}{ Have you ever been advised on oral health by a dentist? } \\
\hline Yes & $95(47.5)$ & $40.6-54.4$ \\
\hline No & $100(50.0)$ & $43.1-56.9$ \\
\hline Not applicable & $5(2.5)$ & $0.3-4.7$ \\
\hline \multicolumn{3}{|c|}{ Do you believe oral health can influence your treatment? } \\
\hline Yes & $199(99.5)$ & $98.5-100.5$ \\
\hline No & $1(0.5)$ & $-0.5-1.5$ \\
\hline \multicolumn{3}{|c|}{ Have you been advised on oral health by your companion/caregiver? } \\
\hline Yes & $71(35.5)$ & $28.9-42.1$ \\
\hline No & $95(47.5)$ & $40.6-54.4$ \\
\hline Not applicable & $34(17)$ & $11.8-22.2$ \\
\hline \multicolumn{3}{|c|}{ Have you been advised on oral health by the hospital nursing staff? } \\
\hline Yes & $95(1.5)$ & $-0.2-3.2$ \\
\hline No & $197(98.5)$ & $96.8-100.2$ \\
\hline \multicolumn{3}{|c|}{$\begin{array}{l}\text { Was your oral health assessed by the hospital nursing staff at } \\
\text { hospitalization? }\end{array}$} \\
\hline Yes & $0(0.0)$ & $0.0-0.0$ \\
\hline No & $200(100.0)$ & 100.0 \\
\hline
\end{tabular}

Source: Authors (2022).

Figure 1. Proportion of hospitalized elderly with some oral health condition.

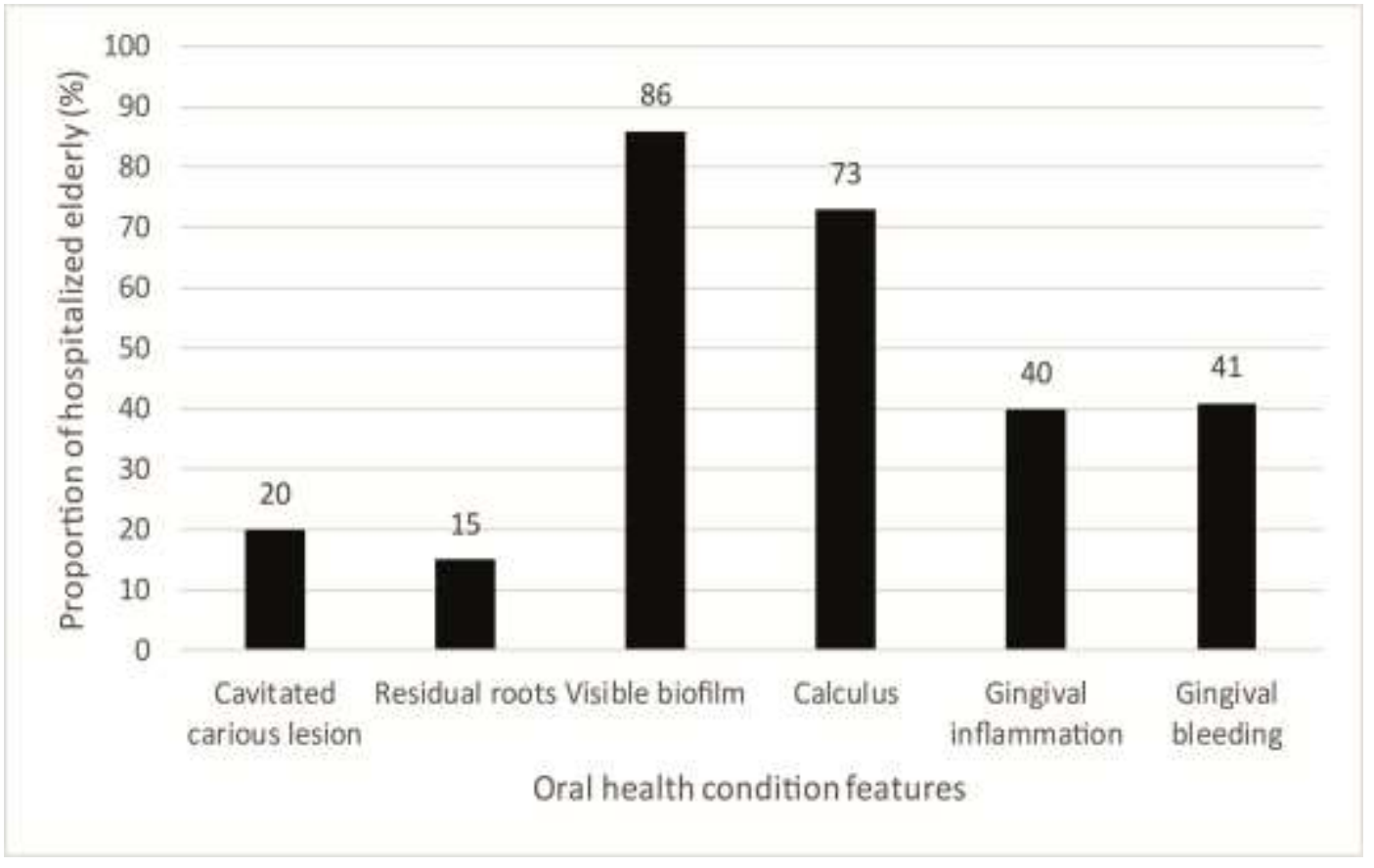

Source: Authors (2022). 


\section{Discussion}

This study addressed the oral hygiene habits and knowledge of hospitalized elderly, their companion and hospital nursing staff of a medium complexity public hospital in the context of the Brazilian Unified Health System before the COVID19 pandemics. It highlights the need for interdisciplinary approaches involving dental professionals and oral health care for hospital nursing staff, caregivers and companions of hospitalized elderly (Lee et al., 2019). This was exemplified by the fact that, although hospital nurses recognize that hospitalized elderly require oral health care, and especially those undergoing mechanical ventilation, they only perform oral hygiene when the elder can not do it (Table 1). Also, although most of them claim to have received information about oral health, almost the totality of them is willing to get instructions on oral health care. Finally, only $29 \%$ of the staff acknowledge the existence of a protocol in oral health care in the hospital.

Demand for additional knowledge on oral health and oral health care by nurses has been identified (Lee et al., 2019; Malik et al., 2018), and this may compromise the treatment of the diasease that caused hospitalization and increase hospitalization time. For instance, aspiration pneumonia is a common compromise of hospitalized elderly usually associated to cognitive decline, disphagia, periodontal disease, lack of oral and denture hygiene and the extubation process (Naruishi et al., 2018; Samanta et al., 2018). Also, denture use during sleep maintains the pressure over the oral soft tissues, increasing the risk of aspiration pneumonia and reducing comfort for the patient (Srinivasan et al., 2019).

Oral health maintenance, especially for gravely compromised elderly, should be performed by the hospital nursing team and by the elderly companions/caregivers (Carrilho Neto et al., 2011b). Simple strategies have been suggested, such as regular oral and dental assessment, daily oral hygiene measures and continuing education of the hospital nursing staff and caregivers (Coker et al., 2017b; Lee et al., 2019; Rantzow et al., 2018). Similarly, it has been suggested that adequate oral hygiene performed on a daily basis reduces the risk of developing oral and systemic diseases and help reducing the hospitalization time (Coker et al., 2017b; Hua et al., 2016; Rantzow et al., 2018).

Most companions/caregivers claimed to perform oral hygiene when the patient is not able to do so, and most claim to do it three times a day or more (Table 2). Also, the majority claim having been advised on oral health care by a dentist. Noteworthy, almost $80 \%$ of the companions were related to the elder and $90 \%$ claimed having received training to take care of elderly. In the Brazilian context, it is not uncommon that formal caregivers have no formal training to take care of older people. Also, formal caregivers have been shown as having limited confidence on their knowledge and abilities related to oral health care (Aro et al., 2018). In another study, caregiving affected more negatively informal caregiver's quality of life and oral health-related quality of life, indicating that training of caregivers is straightforward for a better quality of life of both, the caregiver and the patient (Barbosa et al.,. Still, data in this study does not allow inferences on the level of training received by informal companions/caregivers, as to oral and general care of elderly people.

Almost $90 \%$ of the hospitalized elderly claimed to brush their teeth more than twice a day (Table 3). Yet, most of them claim they do not floss and mouthwash, $86 \%$ present sites of visible biofilm and $73 \%$ present calculus (Figure 1). In a recent systematic review, interdental devices were found to help reducing biofilm or gingivitis or both when associated to toothbrushing more than toothbrushing alone (Worthington et al., 2019). The same review revealed contradictory results with the use of oral irrigators (Worthington et al., 2019). Only 59\% claimed to have brushed their teeth in the research day. Furthermore, $98 \%$ were not instructed on oral hygiene by nursing staff and $100 \%$ claimed that their oral cavity was not evaluated by the nurse (Table 3). The lack of oral hygiene measures by the patient associated to the negligence of oral health care by the hospital staff and companions favour the development of diseases related to pathogenic microorganisms, due to the disruption of the delicate equilibrium of the oral microflora (Castrejón-Pérez et al., 2012; Coker et al., 2017b; Gil-Montoya et al., 2015). Poor oral health in the elderly Brazilian population has been previously described (Brasil, 2011; Lasta et al., 2019), and partially derives from an invasive, mutilating model that favoured dental extraction instead of oral health care orientation. 
Yet, the precarious oral health condition of elderly may hinder systemic recovery in the eventuality of a hospitalization, especially when periodontitis is present (Gil-Montoya et al., 2015).

The study results revealed that $20 \%$ of the hospitalized elderly presented decayed teeth and $15 \%$ presented residual roots (Figure 1). Caries, as a biofilm mediated disease, may be prevented using chemo-mechanical measures of oral hygiene. Toothbrushing with fluoride toothpaste has long been considered as the main oral hygiene measure for prevention of caries (Bratthall et al., 1996). On the other hand, the role toothbrushing frequency plays on oral health maintenance and caries prevention has been controversial. Also, the only systematic review addressing the role of toothbrushing frequency was not able to determine its role on different age groups (Kumar et al., 2016). Regardless, it showed that infrequent brushers (meaning those who brushed less than once a day) had a 1.6 higher odds of having a new decay (Kumar et al., 2016). An aggravating situation is related to the fact that elderly people seldom have received oral health instructions and seldom acknowledge the correct oral hygiene techniques. Still, other confounding factors are associated to toothbrushing as an oral hygiene measure, such as the contact with fluoride, the brushing technique and duration, and the type of toothbrush (Borgnakke \& BrignardelloPetersen, 2017; Kumar et al., 2016). Therefore, assuming that the participants of this study do not acknowledge the toothbrushing technique to adequately perform it, one would expect that the higher contact with the fluoride toothpaste of those who claim to brush their teeth more frequently could offer the protection against cavitation observed.

Other biofilm-induced diseases were observed. Gingival inflammation and bleeding were observed in 40 and $41 \%$ of the participants, respectively, which was a far lower proportion than those who presented visible biofilm (Figure 1), probably indicating biofilm formation during the hospitalization period. A recent review identified educational, exclusively mechanical, exclusively chemical and chemo-mechanical interventions to prevent biofilm accumulation in elderly people (Ruiz Núñez et al., 2021). Professional brushing, educational strategies that included demonstration, sugarless chewing gum and chlorhexidine mouthrinses were found promising, but with short lasting results (Ruiz Núñez et al., 2021). Also, mouthrinses are adjuncts of oral hygiene that present different active principles and mechanisms to act on reduction of gingivitis (Figuero et al., 2019). Recent systematic reviews revealed that antiseptic formulations delivered in the form of mouthrinses help reducing gingival inflammation and bleeding compared to the control group (Figuero et al., 2019; James et al., 2017).

Hospital records revealed that $27 \%$ of the participants had events of ventilation-associated pneumonia, which has been shown to be oral health related and, therefore, preventable by oral health care measures, such as the use of chlorhexidine mouthwash or gel (Hua et al., 2016). This scenario reinforces the benefit of the presence of a dentist or dental hygienist in the hospital environment, either as an instructor on oral health care, a consultor or as a permanent member of the hospital staff.

Limitations of the study were related to its design, which did not allow establishing cause-effect relationships between variables, due to time-related issues. Regardless, it was possible to identify the demand for qualified oral health care in the hospital environment. Future studies could focus on developing and assessing the effectiveness of collaborative educational strategies towards oral health care directed to the hospital nursing staff and companions of hospitalized elderly.

\section{Conclusion}

Oral health care of hospitalized elderly is limited by knowledge and attitudes from nurses, companions/caregivers and the elderly themselves. In general, oral health care habits by hospitalized elderly would benefit from adequate advice by health professionals, especially dentists and dental hygienists. The oral health condition of hospitalized elderly highlighted the presence of visible biofilm and calculus, gingival inflammation and bleeding. Cavitated teeth and residual roots were lower in proportion. 


\section{Acknowledgments}

This study is part of the Master of Science dissertation of the main author. The authors acknowledge that a part-time scholarship was provided by the Universidade Comunitária da Região de Chapecó - Unochapecó during the main author's master course.

\section{Release of conflict of interest}

Mr. Alba worked as a chief nurse in Terezinha Gaio Basso Hospital during his Master of Science course. All other affiliations, corporate or institutional, and all sources of financial support to this research are properly acknowledged and pose no conflict of interest.

\section{References}

Aro, T., Laitala, M., Syrjälä, A. M., Laitala, M. L., \& Virtanen, J. I. (2018). Perceptions of older people's oral health care among nurses working in geriatric home care. Acta Odontologica Scandinavica, 76(6), 427-432. https://doi.org/10.1080/00016357.2018.1425900

Awano, S., Ansai, T., Takata, Y., Soh, I., Akifusa, S., Hamasaki, T., \& Takehara, T. (2008). Oral health and mortality risk from pneumonia in the elderly. Journal of Dental Research, 87(4), 334-339. https://doi.org/10.1177/154405910808700418

Barbosa, C. S., Marchini, A. M., \& Marchini, L. (2013). General and oral health-related quality of life among caregivers of Parkinson's disease patients. Geriatrics and Gerontology International, 13(2), 429-436. https://doi.org/10.1111/j.1447-0594.2012.00926.x

Borgnakke, W. S., \& Brignardello-Petersen, R. (2017). Insufficient evidence to claim that more frequent toothbrushing reduces the risk of developing new caries. Journal of the American Dental Association, 148(4), e1. https://doi.org/10.1016/j.adaj.2016.11.024

Brasil. Ministério da Saúde. (2011). Pesquisa Nacional de Saúde Bucal - SBBrasil 2010 - Resultados principais. Brasília.

Bratthall, D., Hänsel-Petersson, G., \& Sundberg, H. (1996). Reasons for the caries decline: what do the experts believe? European Journal of Oral Sciences, 104(4), 416-422. https://doi.org/10.1111/j.1600-0722.1996.tb00104.x

Carrilho Neto, A., De Paula Ramos, S., Sant'ana, A., \& Passanezi, E. (2011b). Oral health status among hospitalized patients. International Journal of Dental Hygiene, 9(1), 21-29. https://doi.org/10.1111/j.1601-5037.2009.00423.x

Castrejón-Pérez, R. C., Borges-Yãez, S. A., Gutiérrez-Robledo, L. M., \& Ávila-Funes, J. A. (2012). Oral health conditions and frailty in Mexican communitydwelling elderly: A cross sectional analysis. BMC Public Health, 12(1), 773. https://doi.org/10.1186/1471-2458-12-773

Coker, E., Ploeg, J., Kaasalainen, S., \& Carter, N. (2017a). Observations of oral hygiene care interventions provided by nurses to hospitalized older people. Geriatric Nursing, 38(1), 17-21. https://doi.org/10.1016/j.gerinurse.2016.06.018

Crum, R. M., Anthony, J. C., Bassett, S. S., \& Folstein, M. F. (1993). Population-Based Norms for the Mini-Mental State Examination by Age and Educational Level. JAMA: The Journal of the American Medical Association. https://doi.org/10.1001/jama.1993.03500180078038

Ezeh, A. C., Bongaarts, J., \& Mberu, B. (2012). Global population trends and policy options. The Lancet, 380(9837), 142-148. https://doi.org/10.1016/S0140$6736(12) 60696-5$

Fernandes, A. de S., Emiliano, G. B. G., Martins, A. R. de A., \& Souza, G. C. de A. (2016). Conhecimentos E Práticas De Saúde Bucal Por Pacientes Internados E Equipe Hospitalar. Revista Ciência Plural, 2(3), 3-16.

Figuero, E., Roldán, S., Serrano, J., Escribano, M., Martín, C., \& Preshaw, P. M. (2019). Efficacy of adjunctive therapies in patients with gingival inflammation. A systematic review and meta-analysis. Journal of Clinical Periodontology. https://doi.org/10.1111/jcpe.13244

Gibney, J. M., Wright, F. A., D’Souza, M., \& Naganathan, V. (2019). Improving the oral health of older people in hospital. Australasian Journal on Ageing, 38(1), 33-38. https://doi.org/10.1111/ajag.12588

Gil-Montoya, J. A., de Mello, A. L. F., Barrios, R., Gonzalez-Moles, M. A., \& Bravo, M. (2015). Oral health in the elderly patient and its impact on general well-being: A nonsystematic review. Clinical Interventions in Aging, 2015:10, 461-467. https://doi.org/10.2147/CIA.S54630

Hajat, C., \& Stein, E. (2018). The global burden of multiple chronic conditions: A narrative review. Preventive Medicine Reports, 12(September), 284-293. https://doi.org/10.1016/j.pmedr.2018.10.008

Hua, F., Xie, H., Worthington, H. V., Furness, S., Zhang, Q., \& Li, C. (2016). Oral hygiene care for critically ill patients to prevent ventilator-associated pneumonia. Cochrane Database of Systematic Reviews. https://doi.org/10.1002/14651858.CD008367.pub3

James, P., Worthington, H. V., Parnell, C., Harding, M., Lamont, T., Cheung, A., \& Riley, P. (2017). Chlorhexidine mouthrinse as an adjunctive treatment for gingival health. Cochrane Database of Systematic Reviews, 2017(3). https://doi.org/10.1002/14651858.CD008676.pub2

Kahn, S., Garcia, C. H., Galan, J., Namen, F. M., Machado, W. A. S., Da Silva, J. A., \& Egreja, A. M. (2008). Avaliação da existência de controle de infecção oral nos pacientes internados em hospitais do estado do Rio de Janeiro. Ciencia e Saude Coletiva, 13(6), 1825-1831. https://doi.org/10.1590/S1413- 


\section{7}

Kamdem, B., Seematter-Bagnoud, L., Botrugno, F., \& Santos-Eggimann, B. (2017). Relationship between oral health and Fried's frailty criteria in community-dwelling older persons. BMC Geriatrics, 17(1), 1-8. https://doi.org/10.1186/s12877-017-0568-3

Khan, H. T. A. (2018). Population ageing in a globalized world: Risks and dilemmas? Journal of Evaluation in Clinical Practice, (October), 1-7. https://doi.org/10.1111/jep.13071

Kumar, S., Tadakamadla, J., \& Johnson, N. W. (2016). Effect of toothbrushing frequency on incidence and increment of dental caries: A systematic review and meta-analysis. Journal of Dental Research, 95(11), 1230-1236. https://doi.org/10.1177/0022034516655315

Lasta, R., Devilla, A., Simoni, V., Foralosso, J. C., Kellermann, M. G., Marcon, S., \& Rodrigues-Junior, S. A. (2019). Oral health profile of participants of an elderly cohabitation program in the state of Santa Catarina, Brazil. Revista de Odontologia Da UNESP, 48, 1-9. https://doi.org/10.1590/1807-2577.06119

Lee, Y. J., Noh, H. J., Han, S. Y., Jeon, H. S., Chung, W. G., \& Mun, S. J. (2019). Oral health care provided by nurses for hospitalized patients in Korea. International Journal of Dental Hygiene, 17(4), 336-342. https://doi.org/10.1111/idh.12417

Malik, N., Mohamad Yatim, S., Hussein, N., Mohamad, H., \& McGrath, C. (2018). Oral hygiene practices and knowledge among stroke-care nurses: A multicentre cross-sectional study. Journal of Clinical Nursing, 27(9-10), 1913-1919. https://doi.org/10.1111/jocn.14241

Medronho, R. A., Bloch, K. V., Luiz, R. R., \& Werneck, G. L. (2009). Epidemiologia (2nd ed.). Rio de Janeiro: Atheneu.

Murray Thomson, W. (2014). Epidemiology of oral health conditions in older people. Gerodontology, 31, 9-16. https://doi.org/10.1111/ger.12085

Naruishi, K., Nishikawa, Y., Kido, J. ichi, Fukunaga, A., \& Nagata, T. (2018). Relationship of aspiration pneumonia to cognitive impairment and oral condition: a cross-sectional study. Clinical Oral Investigations, 22(7), 2575-2580. https://doi.org/10.1007/s00784-018-2356-7

Oliveira, L. S., Bernardino, I. M., Silva, J. A. L., Lucas, R. S. C. C., \& D’Avila, S. (2015). Conhecimento e prática do controle de higiene bucal em pacientes internados em unidades de terapia intensiva. Revista Da ABENO, 15(4), 29-36. https://doi.org/10.30979/rev.abeno.v15i4.209

Rantzow, V., Andersson, P., \& Lindmark, U. (2018). Occurrence of oral health problems and planned measures in dependent older people in nursing care. Journal of Clinical Nursing. https://doi.org/10.1111/jocn.14584

Razak, P. A., Richard, K. M. J., Thankachan, R. P., Hafiz, K. A. A., Kumar, K. N., \& Sameer, K. M. (2014). Geriatric oral health: a review article. Journal of International Oral Health, 6(6), 110-116. http://www.ncbi.nlm.nih.gov/pubmed/25628498\%0Ahttp://www.pubmedcentral.nih.gov/arti clerender.fcgi?artid=PMC4295446

Ruiz Núñez, M. D. R., da Luz Raulino, M., Goulart Castro, R., \& de Mello, A. L. (2021). Dental plaque control strategies for the elderly population: A scoping review. International Journal of Dental Hygiene, 20(1), 167-181.

Samanta, S., Poddar, B., Azim, A., Singh, R. K., Gurjar, M., \& Baronia, A. K. (2018). Significance of Mini Bronchoalveolar Lavage Fluid Amylase Level in Ventilator-Associated Pneumonia: A Prospective Observational Study. Critical Care Medicine, 46(1), 71-78. https://doi.org/10.1097/CCM.0000000000002774

Srinivasan, M., Delavy, J., Schimmel, M., Duong, S., Zekry, D., Trombert, V., \& Müller, F. (2019). Prevalence of oral hygiene tools amongst hospitalised elders: A cross-sectional survey. Gerodontology, (December 2018), 1-9. https://doi.org/10.1111/ger.12388

Tanaka, T., Takahashi, K., Hirano, H., Kikutani, T., Watanabe, Y., Ohara, Y., \& Iijima, K. (2018). Oral frailty as a risk factor for physical frailty and mortality in community-dwelling elderly. Journals of Gerontology - Series A Biological Sciences and Medical Sciences, 73(12), 1661-1667. https://doi.org/10.1093/gerona/glx225

Van Der Maarel-Wierink, C. D., Vanobbergen, J. N. O., Bronkhorst, E. M., Schols, J. M. G. A., \& De Baat, C. (2013). Oral health care and aspiration pneumonia in frail older people: A systematic literature review. Gerodontology, 30(1), 3-9. https://doi.org/10.1111/j.1741-2358.2012.00637.x

Vieira, J. C., Massoni, A. C. de L. T., Freitas, C. H. S. D. M., Marinho, F. B., \& Costa, C. H. M. Da. (2011). Um olhar sobre os cuidadores de idosos de instituições geriátricas de João pessoa, Paraíba: perfil e cuidados com a saúde bucal dos idosos. Revista Baiana de Saúde Pública, 35(3), 604-618.

Wang, H., Naghavi, M., Allen, C., Barber, R. M., Carter, A., Casey, D. C., \& Zuhlke, L. J. (2016). Global, regional, and national life expectancy, all-cause mortality, and cause-specific mortality for 249 causes of death, 1980-2015: a systematic analysis for the Global Burden of Disease Study 2015. The Lancet, 388, 1459-1544. https://doi.org/10.1016/S0140-6736(16)31012-1

Wang, T. F., Huang, C. M., Chou, C., \& Yu, S. (2015). Effect of oral health education programs for caregivers on oral hygiene of the elderly: A systemic review and meta-analysis. International Journal of Nursing Studies, 52(6), 1090-1096. https://doi.org/10.1016/j.ijnurstu.2015.01.015

Who. (2013). Oral Health Surveys - Basic Methods. World Health Organization, 1.137.

Worthington, H., MacDonald, L., Poklepovic Pericic, T., Sambunjak, D., Johnson, T., Imai, P., \& Clarkson, J. (2019). Home use of interdental cleaning devices, in addition to toothbrushing, for preventing and controlling periodontal diseases and dental caries (Review). Cochrane Database of Systematic Reviews Home, (4. Art. No.: CD012018). https://doi.org/10.1002/14651858.CD012018.pub2.www.cochranelibrary.com 